\title{
Current Situation of China's Financial Consumer Education and Improvement Countermeasures
}

\author{
Meiling Liu ${ }^{1}$, D.M.Power² , B.M.Burton ${ }^{3}$ \\ ${ }^{1}$ School of Accouting and Finance, Wuxi Institute of Commerce, Wuxi, Jiangsu, China \\ ${ }^{2}$ School of Accouting and Finance, University of Dundee, Dundee, Scotland, UK
}

Keywords: China, financial consumer education, current situation, countermeasure

\begin{abstract}
Effective financial consumer education can improve behavior rationality of financial consumers, reduce system behavior deviation and enhance confidence in financial market. So, it gained high attention of many countries. However in China, current education situation of financial consumption is not optimistic, and researches are still in the starting stage and are not perfect. This paper will start from current situation of current financial consumer education, analyze problems and then combine successful experiences of financial consumer education in developed countries including Britain and America to propose some suggestions.
\end{abstract}

\section{Introduction}

Financial consumer education refers to the education which provides basic financial knowledge, financial risk awareness and knowledge of protection of financial consumers' rights and interests. As prevention protection, financial consumer education is an important constituent part in frame system of protection of financial consumers' rights and interests. Financial consumer education is beneficial to the public to master financial knowledge, know financial products, enhance financial skills and improve financial risk awareness.

However, under the background where openness degree of financial industry continuously deepens and financial consumer group continuously grows, the situation of Chinese financial consumer education is not optimistic and relatively lags behind. For example, relevant laws and regulations are not perfect; special protection organizations are deficient; education contents and channels are not rich. These are realistic problems faced by Chinese financial consumer education. The specific current situations are as follows:

\section{Current situation and problems of Chinese existing financial consumer education}

1.1 Financial educational system is imperfect and financial education level is incomplete

(1) At social level, China's financial education system is not perfect. In existing situation, there is no special organization which performs financial education duties. Besides, financial education system norms are not established. There is the lack of scientific and reasonable financial educational mechanism. (2) At school level, financial knowledge popularization in higher education should be the priority among priorities of financial education popularization work. But currently, there is almost no general education curriculum about financial education in Chinese colleges. Although there is general education curriculum about society in elementary education, financial field is almost not involved. (3) At family level, due to influences of Chinese traditional concept, communications about money and financial management between parents and children and among friends are rarely involved, let alone financial education.

1.2 Financial educational concept is obscure and financial educational value distorts

(1) The concept of educational value mismatches. Take financial education of financial organizations for example. As competitions of Chinese financial industry continuously aggravate, some financial institutions have the thought of "valuing marketing and customers and neglecting education". They worry financial education will not just increase cost, but lead to customer loss due to fear of risks, thus influencing economic benefit of financial institutions. Thus, when financial 
institutions carry out financial education, they are not initiative, deep and meticulous. Besides, their practice is single and becomes formalistic. (2) Education deviates from its own track. Because education cannot generate immediate benefits and effects cannot be measured, the essence and purpose of some financial education projects deviate from the track of maintaining consumers' rights and interests, communicating modern financial knowledge, improving consumers' risk awareness and self-protection ability, but become a marketing means of various financial institutions.

1.3 Financial education contents are not all-round and financial education effects are poor

Even if some of the above functional departments and financial institutions have carried out financial education, but education channels are too single and education contents are not comprehensive and even empty. Education media are few and the coverage us small. In terms of publicity form, "publicity month" and "publicity week" can be adopted for temporary financial publicity. There is no continuous and lasting financial publicity activity. Besides, in these publicity activities, financial educators often harbor "favorable social effects" and pay attention to social effects of publicity. They do not pay too much attention to publicity contents, results and objective realization.

1.4 Protect financial consumers' imperfect legal system

Current laws about protection of financial consumers mainly include two aspects: 1) Law on Protection of the Rights and Interests of Consumers issued in 1993 is a fundamental law of protecting consumers' rights and interests; 2) Law of the People's Bank of China, Commercial Bank Law, Law of Insurance and Law on Banking Supervision as well as relevant rules and regulations formulated by People's Bank of China, China Banking Regulatory Commission and China Insurance Regulatory Commission. These laws protect financial consumers to some extent, but the main purpose is to standardize operation order of financial sequences. The legal objective of protecting legal interest of financial consumers is not clear. Besides, they rarely involve protection of financial consumers or just specify principle stipulations with poor operability. In addition, existing laws and regulations also lack specific applicability in the aspect of financial consumers. For example, it is hard for many articles of Law on Protection of the Rights and Interests of Consumers to be suitable for financial field.

In one word, current financial consumption education is poor in China. National financial quality level obviously lags behind development of financial industry. To effectively enhance financial consumption education, it is necessary to know financial education experience of developed countries such as Britain and America, and use their experience for reference to improve level of financial consumption education.

\section{Experience of financial consumption education in Britain and America}

Britain and America as the most advanced countries market economy and financial system started eerily in financial education and always take the lead in the world. The Federal Reserve has positively initiated universal education of financial knowledge since its establishment in 1930s. Financial Services Authority launched organized and targeted financial education from 1998 and has accumulated rich experience.

2.1 Set up financial education promotion mechanism and department

In Britain, Financial Services Authority sets up "Financial Capability Steering Committee" which is especially responsible for formulating and implementing total planning of national financial quality training, and cooperating with relevant units to jointly promote financial knowledge education work.

In America, the Federal Reserve sets up community affairs planning department which is especially responsible for financial knowledge publicity and education and carrying out publicity and education activities with practical contents, novel form and clear objects from national and regional specific groups. In 2006, America especially set up "Financial Knowledge Advisory Committee for President".

2.2 Financial education is normally incorporated in national educational system 
The United States Federal Government issued Financial Illiteracy Elimination and Education Promotion Regulations in 2003 and clearly put forward to bring financial education oriented to national people in state act. New Jersey and other 5 states have passed the legislation to list financial education in required course of 12-year education from formative education to college education and list earning credit of financial course in necessary conditions for students to gain loan. In 2008, Britain brought personal finance in National Education Teaching Programme. Primary and secondary schools must carry out favorable financial knowledge education for graduates. British "Financial Capability Steering Committee" and relevant departments provide teaching materials, curriculum design and teacher qualification certificate for free.

2.3 To carry out characteristic education in allusion to different groups

Since different groups need different financial knowledge. Competent departments of British and American financial education often adopt questionnaire survey to know actual demand of each group and then formulate education plan with pertinence so as to ensure actual effect of educational work.

In 2003, except collecting and classifying information on its official website in allusion to young people, parents, researchers, retirees, employers and teachers, American government also conducted financial education for teachers, middle school students and college students nationwide.

British "Financial Capability Steering Committee" also launched the plan of "helping young people establish financial management concept" in time in 2006 to help cultivate personal financial management ability of young people in allusion to premature and excessive consumption, "those living paycheck-to-paycheck" and "boomerang kids".

2.4 Carryout financial education for vulnerable groups

The main objects for Britain and America to carry out financial education are vulnerable groups and especially low-income people in order to help them apply financial knowledge and seize economic opportunities to get rid of poverty status. American government considers the significance of popularizing financial knowledge for vulnerable groups to help them get rid of plight can be compared with civil rights movement to strive for equality between the black and the white. So, it is also called "money right movement".

2.5 Spread financial knowledge with multiple channels and ways

Apart from regular school education, Britain and America widely spread financial knowledge through multiple channels. For example, Britain utilizes "workplace to impart financial knowledge" and online tools more favored by consumers. Besides, they also help people know financial problems to be faced and the financial products or services contributing to solving such problems through financial affairs consultation. Moreover, consultation services provided by "financial affairs consultation" belong to services for public welfare.

2.6 Provide special funds guarantee for financial education

Funds America use for finical education mainly come from three channels: 1) the federal government will appropriate USD 250 million annually as financial education funds which are equally allocated to middle and primary schools as well as universities from 2009; 2) earnings of Federal Reserve Bank gained from open-market operation and charges for providing paid services for financial institutions; 3) government sector, financial institutions and other organizations provide funds in financial knowledge publicity and education carried out by the Federal Reserve and other financial institutions.

Britain also invests heavily in financial knowledge education. Financial education budget of UK Treasury reached 11.5 million pounds in 2007. After the crisis, the figure increases progressively year after year. British Financial Services Authority will expend about 20 million pounds for financial education, accounting for about $7 \%$ of annual budget.

2.7 Perfect the laws and regulations

America established the important position of financial consumer education in the form of Act of Fair Trade and Credit Verification and brought national financial education in the act in 2003. After the financial crisis broke out, Wall Street Reform and Consumer Protection Act signed by Obama was officially implanted on July 21, 2010. The act highlights two objectives: financial 
prudential regulation and consumer protection and proposed setup of independent consumer protection organization - Consumer Financial Protection Bureau. This organization is given regulation formulation right and regulatory power.

British 2000 Financial Services and Markets Act stipulated financial service supervision bureau had the responsibility of promoting the public to comprehensively know financial system. After the crisis broke out, Britain published 2009 Bank Act which further specified power of financial service bureau in protection of consumers. The white paper of Reforming Financial Markets expounds concrete measures of consumer protection and enhancement of global cooperation of consumer protection.

\section{Suggestions to improve Chinese financial consumer education}

3.1 Set up independent and professional financial consumption education organizations

In view of separated supervision mode of "People's Bank of China, China Banking Regulatory Commission, China Securities Regulatory Commission and China Insurance Regulatory Commission", it is suggested to set up financial consumer education office under People's Bank of China and Consumer Financial Protection Bureau to take charge of finance consumer education, formulate and implement educational program for financial consumers, process and specific tasks. As the important embodiment of financial institutions fulfilling social responsibility, financial institutions should also undertake social duty of financial consumers.

3.2 Construct multi-dimension and all-round financial consumer education system

The government should assume the heavy task of national financial consumer education. Meanwhile, various financial regulators, education sector, financial institutions and financial self-regulation organizations should be brought into financial consumer education system to carry out national financial education in an all-round way.

3.3 Carry out investigation, attach importance to vulnerable groups and formulate scientific and rational education program for financial consumers

Investigations can help know and master objects of financial consumer education and especially differences in demand of vulnerable groups for financial knowledge such as women, children, retirees and low-income people. Financial knowledge publicity and popularization should be brought into national education planning to popularize financial education from elementary and middle education. It is required to cultivate citizens to cognize financial knowledge such as savings, investment, tax payment, income and expenditure and their financial awareness, and formulate scientific and rational financial consumer education program.

3.4 Increase financial knowledge communication approaches and improve financial education modes

Increasing the approaches for the public to gain financial knowledge and improving financial education modes are the inevitable choice of China to popularize financial education.

3.5 Increase input in financial consumer education

It is necessary to refer to experience of developed countries to add fund investment in financial consumer education.

3.6 Perfect law protection system and enhance policy operability

China should refer to American Financial Services Modernization Act or British Financial Services Act, launch Law on Protection of the Rights and Interests of Financial Consumers in good time, specify protection of financial consumers' Rights and Interests and properly solve various contradictory and repeated problems in laws and regulations. Meanwhile, it is required to perfect construction of supporting laws and regulations and enhance policy operability. For example, it is required to formulate Law of Personal Information Secrecy or Credit Investigation Law, enhance punishment force for illegally using personal information, forbid personal financial information from being used for other purposes, issue Financial Institutions Bankruptcy Act or Financial Institution Market Regulations in time, specify property right protection for financial consumers and limit range, achieve effective protection of rights and interests of financial consumers and prevent moral hazard of financial institutions. 


\section{References}

[1] Zhang Jun, Reference of British financial consumer protection system for China [J]. The Chinese Banker, 2008(3): 120-121.

[2] Guo Chen, Unilateral protection rules of American financial consumers and its enlightenment for China [J]. Investment Research, 2010(7): 28-31

[3] Zhou Xiaochuan, Popularize financial education and improve national financial quality. Chinese Finance, 2009(4)

[4] Liu Lei, Exploration of public financial education in the period of post financial crisis. Theory Research, 2011(18)

[5] Yang Lan, Guo Linjie, Wang Changliang, Bernanke, Financial illiteracy elimination month, financial accomplishment and financial education. West China Finance, 2011(6)

[6] Yang Rui, international experience and system reference of financial consumer protection [J]. Modern Management Science, 2010(2): 115-117 